\title{
Türk Tarımında Dijital Teknolojilerin Kullanımı ve Tarım-Gıda Zincirinde Tarım 4.0
}

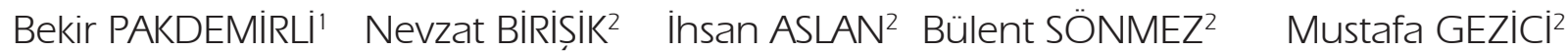

'T.C. Tarım ve Orman Bakanı

Tarımsal Araștırmalar ve Politikalar Genel Müdürlüğü

\begin{abstract}
*Sorumlu yazar e-mail (Corresponding author e-mail): mustafa.gezici@tarimorman.gov.tr
Geliș tarihi (Received) : 17.02.2021

Kabul tarihi (Accepted): 19.03.2021

DOI: $10.21657 /$ topraksu.898774
\end{abstract}

\section{Öz}

İnsanoğlunun en içgüdüsel intiyacı gıdadır. Günümüzde 7 milyardan fazla insan için gıda güvenliğini sağlamak hiç kolay değildir. Birleșmiș Milletler'in tahminlerine göre 2050 yılında Dünya nüfusu 9 milyarı așacaktır. Bu nedenle tarımsal ișlemlerin verimliliğini artırmak için birçok analitik araç kullanarak arazideki değișkenlikleri yönetmek ve birim alandan yüksek verim elde etmek bir gerekliliktir. Dijital teknolojileri kullanarak uluslararası ve yerel pazar taleplerini takip etmek, küresel rekabetçi bir üretime kavușarak GSYIH'ye önemli ölçüde katkıda bulunulabilir. Tarım sektörü, üretim, gıda güvenliği ve beslenme, değișen iklim koșulları, çevresel bozulma, kara deniz biyoçeșitliliğinin kaybı ve uluslararası tarımsal emtia piyasalarının fiyat dalgalanması ile ilgili sayısız zorlukla karșı karșıya kalsa da, modern teknolojilerin, tarımda kullanımının yaygınlașması tarımı bilgi odaklı hale getirmiștir. Dolayısıyla tarım sektöründe dijitalleșmeyi yaygınlaștırmak ve desteklemek son derece önemlidir. Bu nedenle, doğru ve ilgili bilginin doğru zamanda (kullanıcı dostu), uygun formatta ve en uygun iletișim aracının kullanılmasıyla sunulması çok önemlidir, böylece iletilen bilgiler, insanların geçim kaynakları üzerinde bir etkiye sahip olacaktır. Bu çalıșma ile Tarım ve Gıda sektöründe dijital teknoloji kullanımında mevcut durum, sorunlar ve olası çözüm önerilerin Ar-Ge açısından değerlendirmek amaçlanmıștır.

Anahtar Kelimeler: Tarım, Gıda, Dijital teknolojiler, Ar-Ge

\section{Use of Digital Technologies in Turkish Agriculture and Agriculture-Food Chain Agriculture 4.0}

\begin{abstract}
The most instinctive need of man is food. For more than 7 billion people today, ensuring food safety is not easy. According to United Nations estimates, the world population will exceed 9 billion in 2050. Therefore, it is a necessity to manage variability in the land and obtain high efficiency from the unit area by using many analytical tools to improve the efficiency of agricultural processes. Following international and local market demands using digital technologies can contribute significantly to GDP by getting global competitive production. Despite facing numerous challenges related to the agricultural sector, production, food security and nutrition, changing climatic conditions, environmental degradation, the loss of land and sea biodiversity and the price volatility of international agricultural commodity markets, the increment of modern technologies in agriculture has made agriculture knowledge-oriented. Therefore, it is highly important to promote and support digitalization in the agricultural sector. It is
\end{abstract}


also very important that accurate and relevant information is presented at the right time (user-friendly), in the appropriate format and with the use of the most appropriate means of communication, so that the dissemination of knowledge and information will have an impact on people's livelihoods. With this study, it is aimed to evaluate the current situation, problems and possible solution proposals in the use of digital technology in the Agriculture and Food sector in terms of R\&D.

Keywords: Agriculture, Food, Digital Technologies, R\&D

\section{Gíriș}

İnsanlığın yeryüzündeki varlığı 150 bin yıl olarak tahmin edilmektedir. Evrenin 15 milyar, dünyanın ise 4,5 milyar yașında olduğu düșünüldüğünde insanlık tarihi, dünya tarihinin içinde 30 binde birlik küçük bir dilime denk geliyor. Yani dünya 82 yașında bir intiyar ise insanlık bir günlük bir bebektir. İnsanoğlu yeryüzünde 150 bin yıllık serüveninin yaklașı 140 bin yılında yașam tarzında çok büyük değișim olmadan yașamıștır. Sayıları en fazla birkaç yüz bin olan az sayıdaki insanlar yeryüzünde konar-göçer bir yașam sürerken avcllık ve toplayıcilık yolu ile gıda temin ediyordu, bulunduğu yerde gıda biterse, gıda bulabileceği bir bașka yere göç ediyordu. Diğer bir ifadeyle bugünkü anlamılla ne köyler, ne șehirler ne devletler, ne kanunlar ne de sınırlar vardı. Ancak bu rutin ve doğanın kendi döngüsüne uyumlu olan insanlık yașamı bundan yaklașı 12 binyıl önce yani M.Ö. 9500 yllında bir daha geriye dönülmeyecek șekilde değișmiștir. Yerleșik hayata geçilmesiyle birlikte toprağın üretkenliğinin sunduğu imkânları fark ederek üretime yani tarıma geçmișlerdir. Tarım o günlerde emek yoğunken günümüzde bilgi iletișim teknolojilerinin kullanıldığı bilgi yoğun tarıma geçiș olmuștur. Artan nüfus ile birlikte gıda güvenliğini sağlamak için ülkelerin önemli stratejik alanlarından bir tanesi tarımdır. Günümüzde 7 milyardan fazla insan için gıda güvenliğini sağlamak hiç kolay değildir. Birleșmiș Milletler'in tahminlerine göre 2050 yılında Dünya nüfusu 9 milyarı așacaktır. Bununla birlikte günümüzde toprak erozyonu, çölleșme ile iklim değișikliği gibi olumsuzluklar nedeniyle birim alandan daha fazla ürün almak önem arz etmektedir. Üretim maliyetini azaltırken verim artıșını sağlamanın, tarımı yönetmenin en etkili yolu dijital teknolojileri tarımda kullanmaktır. Gıda, insan beslenmesi ve hayatın devamlıı̆ıını sağlamada vazgeçilemezdir. Türkiye'de gıda sektörünün çarpan etkisi ve bağlantıları, diğer alanlarla ilișkileri, istihdam ve döviz kazancı yanında kaynak kullanımı yönüyle ekonomiye ve kırsal gelișmeye katkısı önemlidir. Gıda sektörü, tarımla olan geri bağlantısı ve tüketici ve özelde de dağıtım sektörü, ișleme sürecinde teknoloji ile ilgili ileri bağlantılarıyla sürekli gelișme eğilimi göstermektedir.

\section{Dünden Bugüne Tarım ve Tarım 4.0}

Teknoloji hayatımıza su ve buhar gücünün keșfedilmesi ile 1800'lü yıllarda sanayi sektörü ile girmiștir. 20. yüzyılın bașlarında ise elektrik enerjisinin üretimi ile üretimde makinelere geçiș olmuștur. Tarımda da 1.0 dediğimiz süreç aynı zamanda denk gelmektedir. Așağıda tarımın insanoğlunun yerleșik hayata geçtiği dönemden günümüze kadar geçirmiș olduğu devrimleri görmekteyiz. Bugün yani 21 y.y.'da sahip olduğumuz medeniyetin kurucu unsuru olan "Tarım Devrimlerinin" kısa özetleri ve neden oldukları sosyo-ekonomik sonuçlar așağıda özetlenmiștir (Birișik 2019).

\section{Tarım Devrimi (Bitkilerin ve hayvanların kültüre alınması/Domestification)}

M.Ö: 9500 ile M.S: 700 Bu dönemde yoğun bir șekilde hayvanların evcilleștirmesi ve bitkilerin kültüre alınma çalıșmaları yapıımıștır. İnsanoğlunun temel besin ve enerji kaynağı olan buğday, çeltik, baklagiller, turunçgiller vb. bitkiler bu dönemde kültüre alınmıș, köpek, koyun ve keçi gibi hayvanlar ise yine bu dönemde evcilleștirilmiștir. Bereketli Hilal; birkaç asır sonra Çin'i ortadan ikiye bölerek doğuya doğru ilerleyen Sarı Irmak ile Hindistan'ı kuzeyden güneye doğru bölen İndus Nehri etrafında benzer bir tarım medeniyeti doğmaya bașlamıștır. "Man Power (İnsan Gücü)" dönemi, kısacası bu dönemde ne kadar çok kiși iseniz o kadar güçlüsünüzdür.

\section{Tarım Devrimi (Tarımsal aletlerin geliștirilmesivetarımticareti/Commercialization)}

M.S. 700 ile M.S. 1800 yılları Tarım ișçiliğinde at, katır vb. hayvanlar ile demir sabanın kullanımı, sulama amaçlı kuyu ve su kanallarının yapılması, ticaret yoluyla kültüre alınan bitkilerin bașka yerlere tașınması, üçlü ve dörtlü rotasyon (ekim nöbetinin) sisteminin kullanılması bu döneme denk gelmektedir. Bu dönemin en önemli itici gücü gelișen ticaret ve buna bağlı olarak yeni bitki ve bilgilerin farklı coğrafyalara tașınmasıdır. "Land Power (Arazi Gücü)" dönemi. Ne kadar çok araziniz-toprağınız varsa o kadar güçlüsünüzdür. 


\section{Tarım Devrimi (Endüstriyel tarımın bașlaması//Intansification)}

M.S. 1800-2000 yılları Bu dönemin en belirgin özelliği tohum ıslahına bașlanması, sulama imkân ve kabiliyetinin gelișmesi ve üretimde gübre, așı, tarım ilacı ve makine kullanılmasıdır. Bu yolla tarımsal üretimde; insan sayısına ve arazi varlığına daha az, ancak makine ve girdiye daha çok bağımlı bir sisteme geçilmiștir. Bu süreçte özellikle makine, ilaç ve gübrede geliștirilen teknolojilerin büyük çoğunluğu endüstri devriminin ürünleridir. Bu döneme "Yeșil Devrim" denilebilir. Bu isimlendirme kendi içinde son derece tutarlıdır, çünkü dünyadaki temel gıda üretimi bu süreç içinde yaklașık 15 kat artmıștır. "Hard Power (Zorun Gücü)" dönemi. Ne kadar çok makinanız ve girdiniz varsa o kadar çok güçlüsünüzdür.

\section{Tarım Devrimi (Biyoloji ve teknolojinin birleșmesi/Digitalization): $\mathbf{2} 1$.yy ve sonrası}

Bu dönemde tarımsal üretim; emek yoğun bir süreçten, bilgi yoğun bir sürece, doğal risklere açık bir üretimden, planlama ve kontrollü koșullarda yapılan bir üretime dönüșecektir. Bitki ıslahı, biyoloji ve genetik biliminden daha çok etkilenecek, ülkeler kendi arazi varlığı ile sınırlı olmayan bir üretim modeline doğru yönelecek, bazı girdi piyasalarında monopoli riskleri doğabilecektir. Gelecek dönemde tarım sadece bir üretim ve intiyaç giderme alanı değil, özellikle biyolojik bilgi ve teknolojilerin üretildiği ve bașka sektörlere biyoloji ilminden güç ve know-how aktarılan bir dönem olacaktır. "Bu dönemin adı Smart Power (Akıllı Güç)" olacaktır. Bu dönemin kazananı; çok arazisi, çok insanı, çok makinesi olan değil, ekoloji, biyoloji ve biyoinformatik bilgiye sahip bilgiye ve bilgi üretmeye değer verenler olacaktır.

Tarım devrimi iki temel bileșene dayanmaktadır.

1) Biyoteknoloji: GDO, CRSPR, Hücre kültürü, doku kültürü vb.

2) Bilișim teknolojileri ve yeni nesil mekanizasyon: Tarım 4.0 bu alana verilen isimdir ve iki ana bileșeni vardir.

a. Dijital tarım: (Digital agriculture): Veri toplama

b. Akıllı tarım-Hassas tarım: (Smart/precision farming): Hassas Tarım uygulamaları

Teknoloji hayatımızda su ve buhar gücünün keșfedilmesi ve 1800'lü yıllarda sanayide kullanılmasıyla girmiștir 20. Yüzyılın bașlarında ise elektrik enerjisinin üretimi ile üretim makinelere

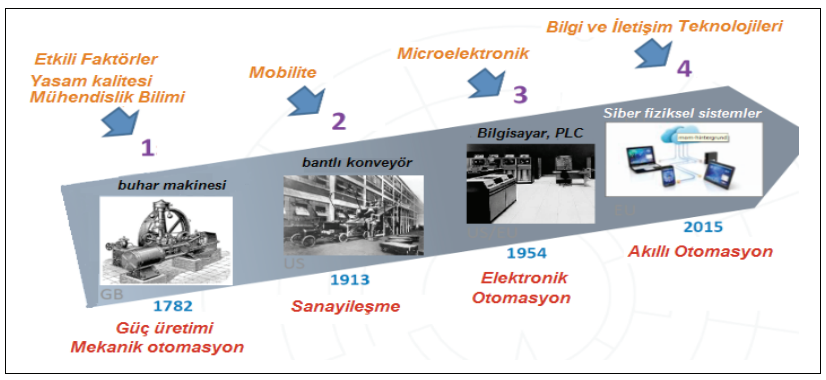

Șekil 1. Sanayi 4.0 ile tarım 4.0 arasındaki teorik bağın açıklanması

geçiș olmuștur. Bu dönemde tarımda makinelere geçiș olsa da bu dönem emek yoğun bir süreçtir. Daha çok insan gücüne dayalı üretim mevcuttur. 1950'lerin sonlarında İkinci Dünya Savașı sonrası elektronik otomasyon sağlanmıș makineler üretim maliyetini düșürmüș daha çok alan ekilebilmiștir ve verimlilik artıșı olan süreç bașlamıștır. 1990'lar sonrası GPS kullanımının açılmasıyla Hassas Tarımın uygulandığı süreç bașlamıștır. Hassas tarım yöntemleri ile arazinin her bir parseline özgü ya da sürüdeki her bir hayvana özgü takip ve çözümler sunulmakta ve üretim maliyetleri azaltılarak süreç daha etkin bir șekilde yönetilmektedir.

2010'lu yıllarda endüstri 4.0 ile sanayide yașanan devrime paralel olarak bilgi teknolojileri tarımda kullanıldığı Tarım 4.0 sürecidir. Bu süreç tarım uzmanlarının daha üretken ve verimli olmalarına yardımcı olan çeșitli araç ve teknolojilerle güçlendirildiği bir üretimdir. Emek yoğun süreçten bilgi yoğun sürece geçiș olmuștur.

Sürecin ana argümanları așağıdaki gibidir.

- Tecrübeye değil; tecrübe + güncel veriye dayalı,

- Popülasyona değil; alana ve bireye dayalı

- Benzerliğe değil; farkııı̆a dayalıdır.

Tarım 4.0 ana amaçları ise așağıdaki gibidir.

- Maliyetleri düsürmek ve verimi artırmak

- Alan veya hayvanı en küçük ölçekte yönetmek

- Beklentiye veya pazara uygun üretim yapmaktır.

Tarım 4.0 sürecinde alandan alınabilecek her türlü veriyi almak, karar destek mekanizması olușturmak, değișken oranlı girdi kullanmak, kendi karar veren sistemler geliștirmek için bütünleșik çiftlik yönetimi mottosu benimsenmektedir. Çeșitli algoritmalar sayesinde büyük verilerin depolanması ve analiz edilerek tarladan sofraya tüm sürecin takip edilebilmesi, yönlendirilebilmesi ve gelecek projeksiyonlarının yapılabilmesi mümkün olmaktadır. 


\section{Mevcut Durum}

Tarımın ekonomik kalkınma için oynadığı kritik rol ve gıda güvenliğini sağlamak için bilgi iletișim teknolojileri ile güçlendirilmesi gerekmektedir. Böylece üretken teknoloji odaklı ve küresel olarak rekabetçi tarımsal üretime kavușulmuș olacaktır. FAO verilerine göre 2050 yılına kadar dünya nüfusunda \% 40 (9-10 milyar), gıda talebinde \% 60-70, sera gazı salınımı \%160, küresel ısınma $4^{\circ} \mathrm{C}$, hastalık ve zararlı baskısında artıș gerçekleșecekken, bitkisel biyoçeșitlilikte \% 36, kiși bașına arazi varlığında \% 24, tarımda kullanılan suda \%24, birim alandaki verimde \% 8 azalma olacaktır. Dolayısı ile birim alandan daha fazla ürün almak ve maliyeti optimize etmek çok önemli bir unsurdur.

Tarımsal GSYH değeri yaklașık 50 milyar dolar ve toplam GSYH içerisindeki payı \% 6,4 civarındadır. İstihdam içerisinde tarımın payına baktığımızda ise yaklașık \%20 civarındadır. Türkiye sahip olduğu tarımsal potansiyeli maksimize etmek için tarımda birçok alanda politikalar geliștirmektedir. Dijitalleșme politikası da bunlardan birisidir.

Dünya tarımındaki küresel eğilimler bireysel gereksinimlerin karșılanmasından çok toplumsal gereksinimlerin karșılanmasına yöneliktir. Küresel rekabet gelișiyor, özellikle Çin ve Hindistan bu değișimde bașrol oynuyor olması diğer ülkelerin tarımsal hedeflerine ulașmada BiT'in potansiyelinden yararlanmayı gerekli kılmaktadır. Ayrıca kırsal nüfus azalıyor olması, tarım yapan nüfus yașlanması, göçlerin artması, israf ve kayıpların artması, toprak bozumu, iklim değișikliği tarımsal suların kirlenmesi gibi nedenlerle; tarımsal üretimde alıșılagelmiș üretim teknikleri ve bunlara ait araçların terk edilerek, çağdaș üretim teknolojilerine geçilmesi ve bunlara uygun araçların kullanılması zorunludur.

Bilgi ișleme ve kullanma süreçlerine ilișkin, birçok araç ve gereç hâlihazırda geliștirilmiș olup piyasada mevcuttur. Bazı Tarım 4.0 Uygulamaları așağıdaki gibidir.

1. Drone teknolojisi

2. Tarım robotları

3. Sulama otomasyonları

4. Değișken oranlı gübreleme sistemleri

5. Otomatik hayvan sağım-besleme sistemleri

6. Sera iklimlendirme otomasyonları

7. Zararlıar için tahmin ve erken uyarı sistemleri

8. Akıllı çiftlik uygulamaları
Bitkisel üretimde akıllı makinalarla değișken oranlı uygulamalar gerek toprak ișlemede gerekse ekim, gübreleme, ilaçlama ve sulama da yapılmaktadır. Özellikle son yıllarda robot teknolojisinin tarımsal alanlarda kullanımının artmasıyla birlikte, değișken oranlı tarımsal uygulamalar konusu öne çıkmaktadır.

Tarımsal ișlemlerde, insan ișgücü yerine, konușlandırılmıș robotlar prototip çalıșmaları gerek özel sektör gerekse akademik saha da devam eden ve üzerinde yapılan Ar-Ge çalıșmalarının hızla artığı yarı/tam otonom araçlardır. Bu araçlar özellikle meyve ve sebze hasadında etkin bir șekilde kullanılabilmektedir. Üzerlerinde kamera ve GPS donanımları mevcuttur. Hasadı otomatik olarak yapan ișleyici organlar sahiptir.

Hayvancilık sektörünün ise rekabet gücünü koruyabilmesi ya da artırabilmesi için hayvan bașına üretim ve aynı zamanda üretimde verimliliğin artırılması gerekmektedir (Aksoy 2003). İnovasyon sosyal ve ekonomik gelișmeyi sağlayabilecek en önemli araçlardan biridir. Tarımda inovasyon bahsi geçen süreçler ile birlikte etkin üretimi sağlayarak büyüme ve kalkınmayı hızlandırıcı ve bir etkiye sahiptir. Verimliliğin artırılmasında en önemli unsur ileri teknolojinin tüm çiftçiler için ulașılabilir olmasıdır. Bu teknolojiler çiftlik bașına daha fazla hayvanların yönetilmesine olanak sağlarken hayvanlarla bireysel olarak ilgilenmeyi destekler ve refah düzeyini arttıır.

Akıllı Tarım Teknolojileri küçük ve orta ölçekli çiftçiler ve tarımsal ișletmeler tarafından kullanılabilir ve erișilebilir olup sürdürülebilir üretimin temel dayanak noktası ise Ar-Ge'dir. Akıllı Tarım Teknolojilerine yönelik yürütülen çalıșmalardan bazıları așağıda verilmiștir.

\section{- Traktörlerde Otomatik Dümenleme Sistemi}

ile hava șartlarından etkilenmeden (gece bile), hiç aralık bırakmadan ya da üst üste bindirmeden daha hızı ama hassas ișleme, hep aynı yoldan gidildiği için daha az toprak sıkıșması, neredeyse sıfira inmiș operatör yorgunluğu, sıfır hata riski ve operatör memnuniyeti, sonraki ișlerde (hasat vs) kolaylık ve yakıt, ilaç, tohum, gübre ve ișçilikten tasarruf mümkün olmaktadır. \%12'ye varan oranlarda yakıt tasarrufu, Gece çalıșma imkanı, Üst üste ekim, ilaç ve gübre uygulamasını engeller ya da ekilmemiș, ilaçlanmamıș ya da gübrelenmemiș yer bırakmaz. 2015 yılında yayınlanan bir makaleye göre Çin'in Heilongjiang bölgesinde en popüler hassas tarım teknolojisi Otomatik Dümenlemedir. (Kaynak: TAGEM/15/ AR-GE /78 proje kodu ile GAP Tarımsal 
Araștırma Enstitüsü Müdürlügü, Ankara Tarla Bitkileri Merkez Araștırma Müdürlüğü ve ASELSAN ortaklığı ile Kamu Özel Sektör Ar-Ge projesi bașlatılmıș olup, 2017 yılında proje sonuçlanmıștır.)

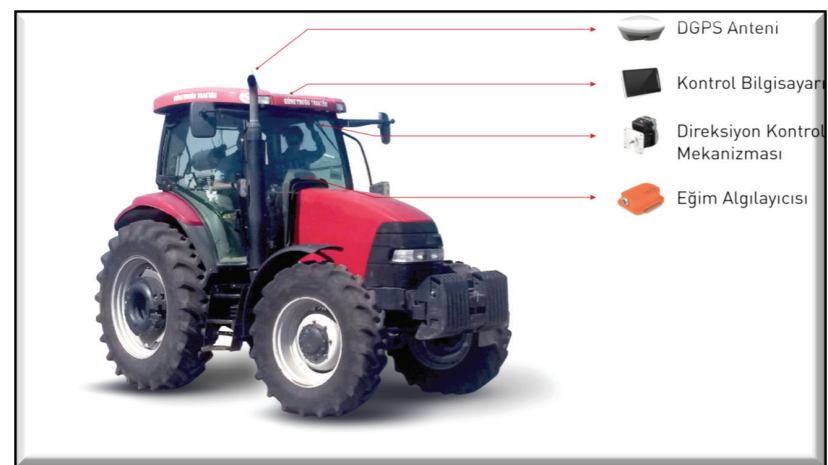

Șekil 2. TAGEM ve ASELSAN ortaklığı ile geliștirilen Yerli OTAK

\section{- İnsansız Hava Aracı ile Görüntü İșleme} Temelli Hassas Tarım Uygulamaları Projesi ASELSAN'ın ARI-1 Döner Kanatlı İnsansız Uçan Sistemi ile toprak, kuraklık, gübre durumu, hasat tahmini, rekolte hesabı ve farklı ürünler için bir kütüphane olușturulmasına yönelik altyapı kurulacaktır. Altyapı kurulduktan sonra, tarım sigortalarına yönelik hasar tespit çalıșmalarında da kullanım imkânları doğabilecektir. (Kaynak: TAGEM/15/ AR-GE /77 proje kodu ile Ankara Tarla Bitkileri Merkez Araștırma Müdürlüğü ve ASELSAN ortaklığı ile Kamu Özel Sektör Ar-Ge projesi bașlatılmıș olup, 2017 yılında proje sonuçlanmıștır).

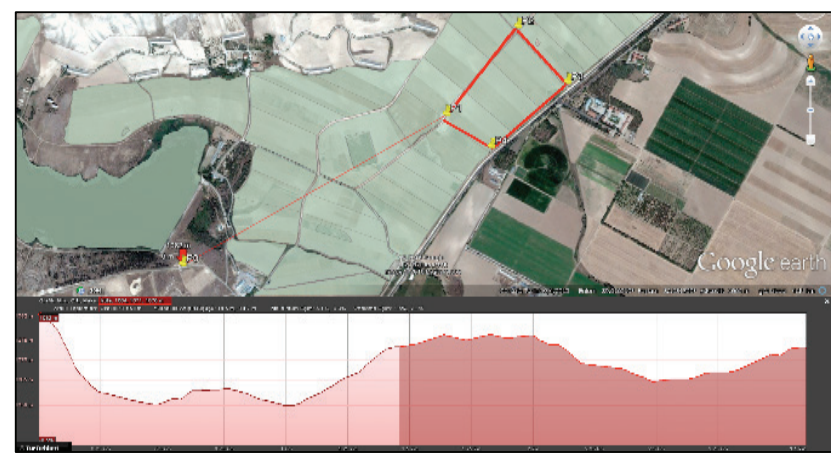

Șekil 3. Haymana İkizce lokasyonun multispektral kamera ile alınan buğday tarlası görüntüsü

\section{- Çiftlik Yönetim Sistemi Geliștirildi:} Ciftlik Yönetim Sistemi, tarımsal döngünün tüm süreçlerine dair veri toplama, izleme, değerlendirme ve karar verme süreçlerini entegre bir șekilde ele alan bilgi sistemidir. Teknoloji kullanımında dünyanın yașadığı son endüstriyel devrimin yani Endüstri 4.0 sürecinin, tarım teknolojilerine olan yansıması, tarımsal verimliliği çok daha üst bir seviyeye çıkarmaktadır. Bu süreçte, traktörler ve bağlı oldukları ekipmanlar, tüm üretim sürecinde birbirleriyle iletișim halinde olacaklardır. TAGEM-ASELSAN ișbirliği ile gerçekleștirilen projede tarım araçları üzerindeki uluslararası ISO 11783 Standart ara yüzünde toplanan mesajların, telsiz linki üzerinden uzak mesafeye aktarılarak haberleșilmesine, toplanan verilerin harita üzerinde ișlenmesine, tarihsel olarak görüntülenmesine ve analiz edilmesine imkan sağlayacak yazılım geliștirilmiștir. (Kaynak: TAGEM/15/AR-GE/76 proje kodu ile Ankara Tarla Bitkileri Merkez Araștırma Müdürlüğü ve ASELSAN ortaklığı ile Kamu Özel Sektör Ar-Ge projesi bașlatımıs olup, 2017 yılında proje sonuçlanmıștır.)

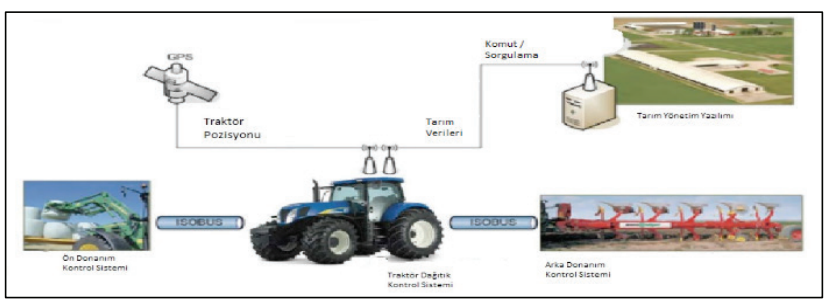

Şekil 4. OTAK ve İHÁnın koordinasyonunu sağlayan Çiftlik Yönetim Sistemi projesi

- Ülkesel Hassas Tarım Projesi: Proje ile gereğinden fazla kimyasalların kullanımı ile olușacak çevre kirliliği, planlı programlı ve analize dayalı bir girdi kullanımı ile azaltılacaktır. Yüksek maliyetli tarımsal girdilerin çiftçi üzerinde olușturduğu ekonomik baskılar analize dayalı girdi kullanımı ile engellenecektir. (Kaynak: TAGEM / TSKAD /16/A13/P08/15 ve TAGEM/TSKAD/E/19/ A9/P8/1 102 proje numaraları ile Bahri Dağdaș Uluslararası Tarımsal Araștırma Enstitüsü ve Tarla Bitkileri Merkez Araștırma Enstitüsü tarafindan yürütülmektedir.)

- Merkezi Dane Kaybı İzleme ve Takip Sistemi Hasatta tahmini dane kaybı yaklașık 1,77 milyon ton, toplam ekonomik etkisi 2,4 milyar TL'dir. Eylül 2015'te Birleșmiș Milletler tarafından kabul edilen Sürdürülebilir Kalkınma Hedefleri (SKH) bünyesinde, "2030'a kadar perakende ve tüketici düzeylerinde kiși bașına düșen küresel gıda atığının yarıya indirilmesini ve hasat sonrası kayıplar dâhil üretimdeki ve tedarik zincirlerindeki gıda kayıplarının azaltılması" hedeflenmiștir. Bu proje ile Bulut tabanlı sistemde dane kaybının anlık olarak operatör ünitesinde görüntülenmesi anlık olarak merkezi izleme sistemine iletilmesi hasat așamasında GSM sinyali olmadığında offline veri depolanması ve internet bağlantısının ilk 
kurulduğu anda merkeze verilerin iletilmesi merkezi altyapı üzerinden hasat yapan biçerdöverlerin anlık konumu, ișlem/kayıp durumu bilgilerinin mobil ve web tabanlı uygulama altyapıları ile izlenmesi sağlanabilecektir. (Kaynak: TAGEM/17/ Ar-Gel18 kodu ile Toprak Gübre ve Su Kaynakları Merkez Araștırma Enstitüsü Müdürlüğü ile ODTü TEKNOKENT-GEOSYS Firması ortaklığı ile Kamu Özel Sektör projeleri kapsamında yürütülmektedir.)

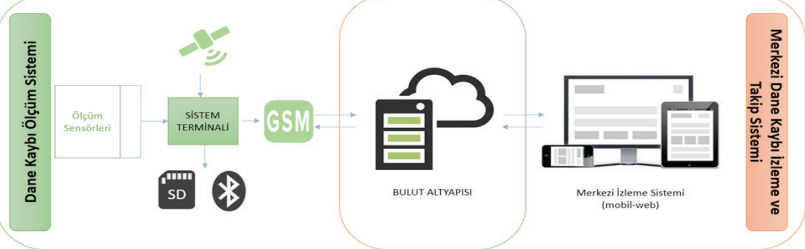

Șekil 5. Dane Kaybı İzleme sisteminin iș akıș șeması

- Örtüaltı Sebze Yetiștiriciliğinde Kullanılmak Üzere Kendi Yürür Pülverizatör Tasarımı: Örtüaltı üretim yapan çiftçilerimizin büyük bir çoğunluğu gerek tarım ilaçlarının uygulanma yöntemlerinde ve gerekse kullanılması gereken ilaç miktarlarında önemli hatalar yapmaktadırlar. Bu proje kapsamında örtü altı tarımında kullanılmak üzere uzaktan kumanda edilebilen kendi yürür pülverizatörün tasarımı ve imalatı yapılmıștır. (Kaynak: TAGEM-BS-10/10-01/03-01 proje numaraları ile Bornova Zirai Mücadele Araștırma Enstitüsü tarafindan yürütülmüstür.)

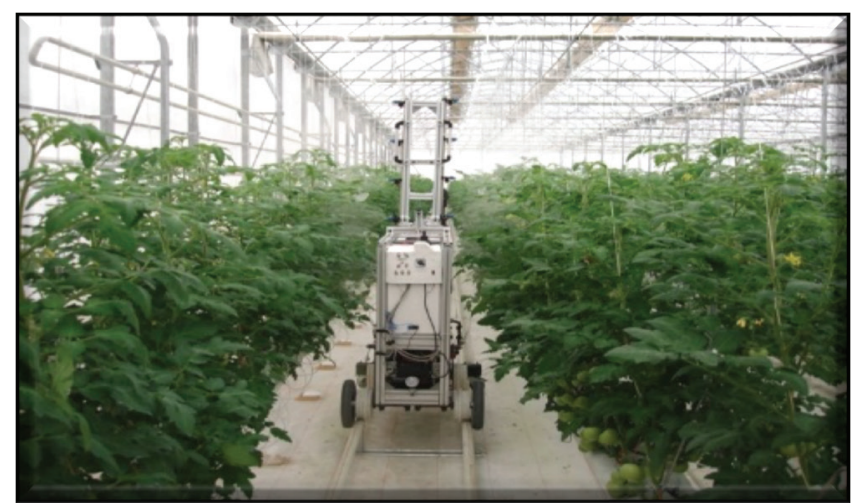

Șekil 6. Yerli örtü altı robotik ilaçlama

- BuğdayınÖnemliZararlısıSüneyle Mücadelede Yapay Zeka Kullanılarak Tahmin Uyarı Sistemi: Bu çalıșmada sünenin tüm biyolojik dönemleri ve yașam döngüsü ile iklim verileri arasındaki ilișki ortaya konulmuș, mücadeleye esas olmak üzere yapay zekâ tekniklerinden yararlanılarak, sürvey ve mücadele zamanını en az hata ile belirleyen bir tahmin-uyarı sistemi olușturulmuș, prototip yazılımı yapılarak iki yıl süre ile Aksaray ve Kırșehir illerinde yazılımın güvenirliliği test edilmiștir. IKaynak: TAGEM-BS-12/12-01/01-03 proje numarası ile Zirai Mücadele Merkez Araștırma Enstitüsü Müdürlüğü tarafından yürütülmüștür.)

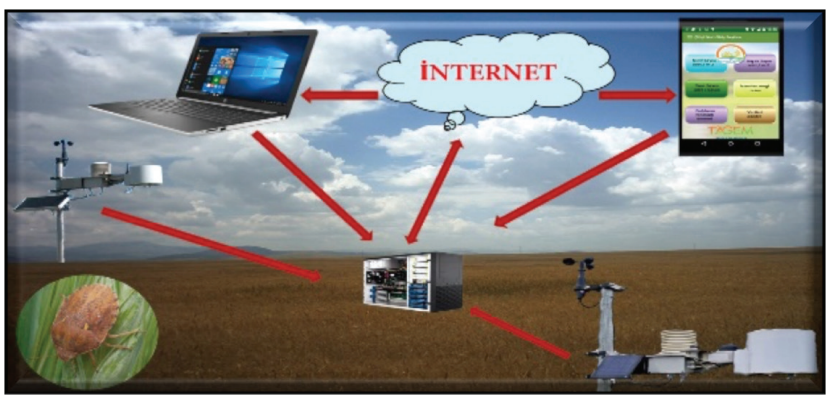

Șekil 7. Süne Uyarı Sistemi iș akıș șeması

- Hayvan Takip Sistemi geliștirme çalıșmaları

bașladı. Dünyada bir ilk olan "Hayvan Takip Sistemi' ile hayvanların canlı olup olmadığı, hangi koordinatlarda bulunduğu gibi bilgilerle her zaman hayvanların tam sayımını sağlayacak ve sanal karantina uygulamaları, el terminalleri ile hayvan sağlığı hizmetlerinde uygulayıcılara kolaylıklar sağlayarak ișletme yönetimi basitleștirilecektir. Ayrıca belirli hayvan davranıșlarının (kızgınlık, ruminasyon karakteristiğinin, kulak iç yüzey sıcaklığı değișimi değeri) hayvan takip cihazından elde edilecek veriler kullanılarak hayvan takip sistemi yazılımında Ar-Ge kapsamında analiz edilmesi planlanmaktadır. Söz konusu proje da yaygın pilot uygulaması gerçekleștirilecektir. Yaklașık 20.000 adet büyükbaș hayvan sisteme dahil edilerek izlenecektir. Toplanan veriler makina öğrenmesi ile algoritmalar olușturulacaktır. (Kaynak: Proje, TAGEM Uluslararası Hayvancılık Araștırma ve Eğitim Merkezi Müdürlüğü ve ASELSANNET tarafindan yürütülmektedir.)

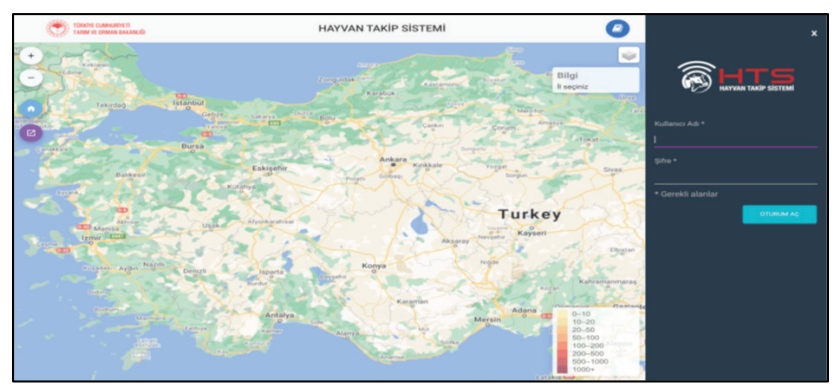

Șekil 8. Elektronik Hayvan Takip Sistemi Arayüzü

Dünya'da 1990'ların bașından itibaren bilgi teknolojilerinin gelișimiyle, insana, bitkiye, hayvana ve çevreye duyarlı, üretimde kalite 
ve verimlilik faktörlerini ön planda tutan bir değișim süreci geçirilmektedir. Bu değișime ayak uydurmak ve rekabet gücünün artırılmasında kilit bir unsur Ar-Ge çalıșmalarıdır. Türkiye'nin en büyük Ar-Ge organizasyonu olan Tarım ve Orman Bakanlığı Tarımsal Araștırmalar ve Politikalar Genel Müdürlüğü Tarım 4.0 konusunda kendi enstitülerinde yapmıș olduğu çalıșmalara ilaveten özel sektöre de destek vermektedir. Rekabet gücünün artırılabilmesi ise; eğitimli ve kaliteli insan kaynağına, doğal kaynakların verimli kullanılmasına ve geliștirilmesine ve teknolojik gelișmelere hızı bir șekilde uyum sağlamaya bağlıdır. Çeșitliliğin arttığı, rekabetin kızıștığı ve sınırların ortadan kalktığı piyasa koșullarında, sürdürülebilir üretimin temel dayanak noktası Ar-Ge ve inovasyon olarak ortaya çıkıyor. Ar-Ge harcamaları aynı zamanda bir yatırım niteliğindedir ve öyle ki Ar-Ge yatırımları için yapılan harcamalar yapılan harcama miktarından daha fazla bir getiri sağlayacağından ötürü bu harcamalar yapılmaktadır (Ağır ve Utlu, 2011: 269-280). Tarımsal Araștırmalar ve Politikalar Genel Müdürlüğü olarak Tarım 4.0 konusunda özel sektöre vermiș olduğumuz destek miktarı 2020 yılına kadar 7 milyon TL olduğu saptanmıștır.

\section{Türkiye'nin Diğer Ülkeler İle Karșılaștırılması}

CEMA (Avrupa Tarım Makineleri Birliği) "Tarım 4.0: Tarımın Geleceği" Raporu'nda, Avrupa'da yıllık cirosu 26 milyar avro olan, 450 farklı tarım makinesi üreten 4.500 üretici olduğu ve bu sektörde 135.000 kișinin istihdam edildiği belirtilmektedir. Aynı rapora göre, Avrupa'da satılan yeni tarım ekipmanlarının \%70 ile \%80'inde hassas tarım teknolojisi bileșeniyer almaktadır. Akıllı tarım uygulamalarının 2030 yılına kadar, tarım sektörünü en fazla etkileyecek olan faktör olacağı ve $A B$ tarımının sürdürülebilirliğinin sağlanmasında itici rol oynayacağı bu raporda vurgulanan bir bașka noktadır.

ABD Federal Tarım Departmanı hem üretim için entegre teknolojilere teșvikler vermekte hem de çiftçilere tarımsal teknoloji kullanabilmeleri için çeșitli destek imkanları sunmaktadır. İsrail, tarım teknolojilerinden özellikle sulama sistemleri, biyoteknoloji ve atık suyun yeniden kullanımına yönelik teknolojileri desteklemektedir. Öyle ki, tarım teknolojileri alanında yapılan araștırma geliștirme harcamaları, İsrail'in bütçesinin \%17'sini olușturmaktadır. İsrail tarım sektörünün dönüșümünde, tarım teknolojisi alanındaki yeni teknolojik girișim șirketlerinin etkisi büyüktür. Japonya Tarım, Ormancılık ve Balıkçılık Bakanlığı́nın yayınladığı Gıda, Tarım ve Kırsal Alanlar Yıllık Raporu'na (2016) göre, girdi maliyetlerinin azaltılmasında en önemli etken olarak tarımsal teknolojiler görülmektedir. Teknolojik gelișmeler sayesinde, Japonya'nın tarım inracatı \%24 artarak 35 milyar dolarlık gelir sağlanmıștır.

AB'deki tarımsal ișletmelerin \%86'sı 20 hektarın altında bir alana sahip olup Avrupa kırsal ekonomisi ise büyük ölçüde küçük tarımsal ișletmelere bağlıdır. Bununla birlikte mevcut durumda çiftçilerinin \%25'inden daha azı akıllı tarım teknolojilerine erișim sağlayabilmektedir. 50 ha'dan küçük çiftliklerin büyük çoğunun hassas teknolojilere yeterince erișimi yoktur. 100 ha'dan büyük çiftliklerin büyük çoğunluğunun ise temel akıllı tarım teknolojilerinden en azından birine erișimi vardı*. 100 hektarın altındaki çiftlikler (AB'deki tarım ișletmelerinin \%97'si) için akıllı tarım teknolojilerinin alımını destekleyecek bir eylem planının olmaması halinde bu çiftliklerin ABD, Kanada ve Yeni Zelanda'daki çiftliklerle rekabet edebilmesinin zorlașacağına vurgu yapılmıștır. Avrupa'da satılan yeni tarım ekipmanlarının \%70 ile \%80'inde akıllı tarım teknolojisi bileșeni yer almaktadır. Avrupa'da satılan yeni tarım ekipmanlarının \%70 ile \%80'inde akıllı tarım teknolojisi bileșeni yer almaktadır

Tarım ve Makine Sanayi Etkileșimi Raporunda belirtildiği üzere ülkemiz Tarım Makineleri Sektöründe ulașılan konum dıș ticaret verileri üzerinden değerlendirildiğinde, daha ölçülebilir sonuçlara ulașılmaktadır. Buna göre 2000'lerin bașinda 20-30 milyon USD seviyesinde ekipman, 30-40 milyon USD seviyesinde traktör inracatı yapan ve dıș ticaret açığı veren Türk Tarım Makineleri Endüstrisi, bugün 1 milyar USD seviyesini așan inracatı ile dıș ticaret dengesini kurmaya hatta fazlasını vermeye bașlamıștır. Bu değișim, inracat sıralamasından da izlenebilir. 2001 yilında 31. sırada olan ve toplam inracattan binde 3 pay alan Türkiye, 2019 yılını 16. sırada tamamlamıș ve toplamdan aldığı payı binde 15'e yükseltmiștir.

Modern tarımın en önemli göstergesi olan traktör elektrikli olması ile yenilikçi bir yaklașım kazanmıștır. Almanya'da sektörün öncü bir firması, gerçek çalıșma koșullarında 5 saate kadar çalıșabilen 50 kW güç çıkıșlı bir bataryalı kompakt 
bir elektrikli traktörü 2017 yılında deneme amaçlı olarak piyasaya sürmüștür. Elektrikli traktörler konusunda Çin'de, Hindistan'da, İsviçre'de ve Kanada'da çalıșmalar mevcuttur. Ticarileșme kısmında Hindistan ve Çin bașı çekmektedir.

Tarım ve Orman Bakanlığı tarafından 2019 yılında bașlatılan çalıșma kapsamında Tarımsal Araștırmalar ve Politikalar Genel Müdürlüğü (TAGEM) öncülüğünde bir prototip geliștirilmiștir. 75kW (105 BG) gücündeki tarla sınıfı bu elektrikli traktör, 4 teker tahrikli manevra ve dümenleme kabiliyetine sahiptir. 236 adet prizmatik LiPO4 bataryanın seri olarak bağlanmasıyla 53 kWh batarya kapasitesine ulașıldığı, batarya șarj sisteminin kablolu șarj fiși (plug-in) bağlantısına uygun bir șekilde tasarlandığı ve șarj için trifaze prize intiyaç duymaktadır.

Saha denemeleri Tekirdağ Bağcılık Araștırma Enstitüsünde yapılan elektrikli traktörün, muadili dizel traktörle karșılaștırmalı denemelerinde 4 soklu pulluk ile $30 \mathrm{~cm}$ iș derinliğinde çalıșma koșulları için 500 saatlik kullanımda elektrikli traktör için yıllık enerji maliyeti 11.992,25 TL ve dizel yakıtlı traktörde yıllık yakıt maliyeti 96.525 TL olarak hesaplanmaktadır. Bu rakamlar sonucunda elektrikli traktör ile dizel traktör arasında yakıt masrafı olarak 8 katlık farkı ortaya koymaktadır.

Denemeler ve hesaplamalar tarımsal mekanizasyonda en çok güç gerektiren toprak ișleme iși üzerinden yapılmıștır. Ekim, bakım ve gübreleme ișleri dikkate alındığında tüketimler doğru orantılı șekilde düșecektir. Elektrikli traktör yaklașık 1,7 kat daha fazla güç olușturmuș 8 kat daha az yakıt tüketmiștir.

Diğer bir prototip ise 65 BG gücünde elektrikli bahçe traktörüdür. Proje kapsamında özgün șasi tasarlanmıș olup dıș tasarım ile ilgili tasarımcı ile çalıșılmaktadır. 65 BG gücünde elektrikli traktör prototipi atölye așamasında olup tamamlanmak üzeredir. İșletme maliyetlerinin elektrikli traktör ile birlikte 20'de 1 seviyelerine düșmesi beklenmektedir. (Kaynak: Projeler, TAGEM; Toprak Gübre ve Su Kaynakları Merkez Araștırma Enstitüsü, Tekirdağ Bağcılık Araștırma Enstitüsü, Ankara Tarla Bitkileri Merkez Araștırma Enstitüsü ve TREV firması ișbirliği ile yürütülmüștür.)

Makinaların giderek daha kapasiteli ve deyim yerindeyse "akıllı" hale geldiği bir dönemde, FAO- TAGEM İșbirliği ile TCP-Ulusal E-Tarım Stratejisinin Geliștirilmesinin Desteklenmesi Projesi bașlatılmıștır. Projenin amacı Türkiye tarımında dijitalleșmenin mevcut durumunun tespit edilmesi, iyi uygulama örneklerinin ortaya konulması ve Ulusal E-Tarım Stratejisinin geliștirilmesidir. Tarımsal Araștırmalar ve Politikalar Genel Müdürlüğü koordinasyonunda çalıșmalara bașlanmıștır. Proje Bakanlığımızın tüm uygulayıcı ana hizmet birimlerinden hem teknik düzeyde hem de yönetici düzeyde temsili ile yürütülmektedir. (Kaynak: Projede Ziraat Odaları Merkez Birliği, Bilgi Teknolojileri ve Iletișim Kurumu, Haberleșme Genel Müdürlüğü, Ankara Üniversitesi projenin ana paydașıdır.)

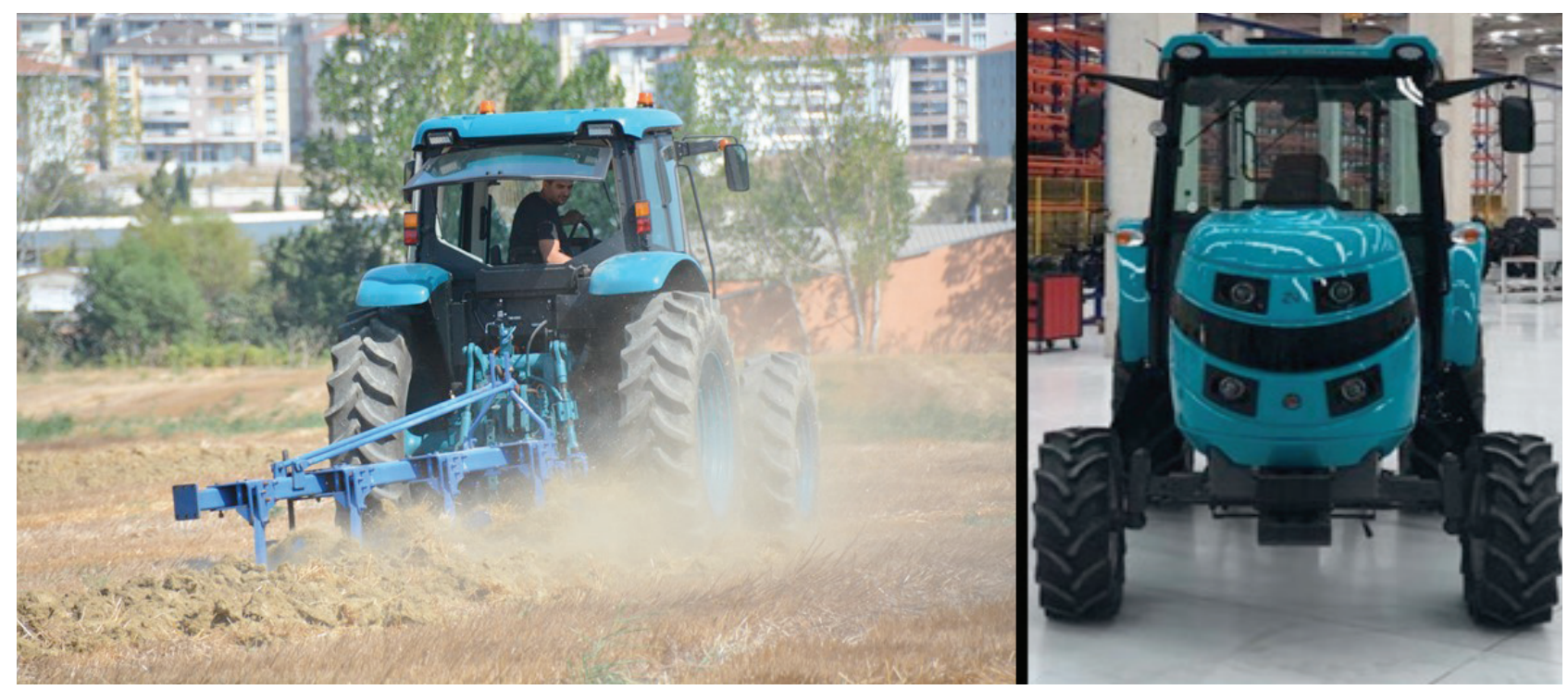

Șekil 9. 105 BG gücünde Yerli Elektrikli Traktör Prototipi (TAGEM) 


\section{Tarım 4.0 Gelecek Beklentileri}

FAO tarafindan hazırlanan "How to Feed the World in 2050" adlı çalıșmada, 2017 yılı itibarılyla yaklașı 7 milyar nüfusa sahip dünyada nüfusun 2050'de yüzde 34 artıșla 9,1 milyara ulașacağı ve dünya nüfusunun beslenmesi sorunu tüm ülkelerin ve uluslararası kurulușların öncelikli politika alanlarından birisi olacağı belirtilmektedir. FAO bu artıșların sağlanması için verim ve ürün alma yoğunluğu artıșının yanında ülkelerin tarımsal ArGe alanına yatırımlarını yönlendirmesini ve bu alana politika önceliği vermesini tavsiye etmektedir. Türkiye tarafından FAO çalıșmasında belirtilen hususların dikkate alınması ve özellikle tarımsal Ar-Ge ile bahse konu üretim artıșlarının sağlanması için gerekli çalıșmaların sürdürülmesi önem arz etmektedir.

FAO genel olarak 2050'de dünya nüfusunun 9 milyar olacağından ve 2050'de gıda intiyacında \%60 artıș daha yüksek olacağından hareketle küresel tarım ve gıda arzının artması gerektiğini ifade etmektedir. FAO yaptığı çalıșmaları dünya açlık haritası olarak yayınlamaktadır. Șekil 15'te FAO tarafından hazırlanan 2018 yılı dünya açlık haritası aörülmektedir.

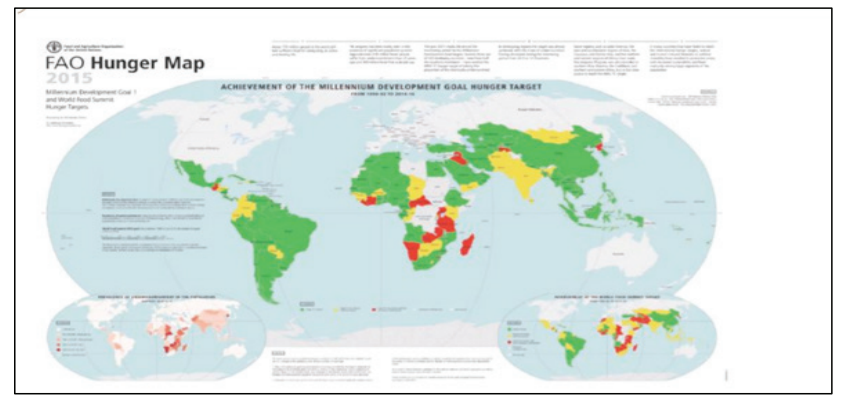

Șekil 10. FAO 2015 Dünya Açlık Haritası (Kaynak: FAO)

Haritada kırmızı olan yerler șiddetli ve kronik açlığın yașandığı sarı olan yerler ise açlık ve yetersiz beslenmenin görüldüğü, yeșil alanlar ise bugün için bir açlık sorunu olmayan, gri boyalı ülkeler ise veri alınamayan veya açlıkla ilgili sorunu olmayan ülkeleri tarif etmektedir. FAO bir ülkedeki açlık durumunu ise 5 seviyede ölçmektedir. İnsanlık geçmiște de, bugünde gıda yetersizliğinden yani açlık veya kıtlıktan dolayı çok kayıp vermiștir, vermeye de devam etmektedir Biyoloji-teknoloji birlikteliğinin geliștireceği Drone ile ilaçlama, izleme, biyoteknoloji uygulamaları, moleküler ıslah ve kapalı alanlarda yapılacak bilimsel çalıșmalar
Hayvancilık sektöründe teknoloji kullanımının artması nedeniyle akıllı tarımın önümüzdeki dönemde sektörde ileri teknolojili mekanizasyonun kullanılması açısından önemini koruması beklenmektedir. Ayrıca nesnelerin interneti (internet of things) ile bağlantılı sürü yönetimi sistemi, sağlık, besleme ve verimlilik takibi sistemleri gibi birçok sistemin geliștirilerek gelecekte sektörün kullanımına sunulması beklenmektedir.

\section{SONUÇLAR}

Türkiye dünyanın en büyük 10 tarımsal ekonomisi arasında yer almakta ve Avrupa'nın en büyük tarımsal üreticisi konumundadır. Öte yandan sahip olduğu tarımsal alan varlığı, görece genç nüfusu, orta doğu, Avrupa, Orta Asya gibi pazarlara yakınlığı düșünüldüğünde önemli bir potansiyele sahiptir. bilgi ve iletișim teknolojilerini değer zincirinin tüm așamaları için tarıma entegre ederek sahip olunan bu tarımsal potansiyelden maksimum derecede yararlanabilmektir. Potansiyeli maksimize etmek için tarım sektöründe dijitalleșmeyi yaygınlaștırmak ve desteklemek son derece önemlidir.

Küçük çiftçilerin desteklenmesi ve arazi, teknoloji ve piyasalara eșit erișimlerini destekleyen sürdürülebilir tarım uygulamalarının teșvik edilmesi ile beraber tarımda verimliliği artırmak için altyapı ve teknolojiye yatırım yapılması gerekmektedir. Böylece rekabetçi bir üretim ile gıda güvenliği sağlanabilir.

Çeșitliliğin arttığı, rekabetin kızıștığı ve sınırların ortadan kalktığı piyasa koșullarında, sürdürülebilir üretimin temel dayanak noktası Ar-Ge ve inovasyon olarak ortaya çıkmaktadır.

Özellikle Tarım makineleri endüstrisinde yeterli ölçüde Ar-Ge yapıldığından söz edilmesi mümkün değildir. Çalıșmalar daha çok ürün geliștirme olarak tanımlanır. Bakanlığımız sektördeki Ar-Ge açığını ortadan kaldırmak için Tarımsal Mekanizasyon Alt Yapı Geliștirme projesi ile Tarım ve Orman Bakanlığı TAGEM Araștırma Enstitülerinde tarımsal mekanizasyon ve bilișim teknolojileri düzeyinde dünyanın ileri teknolojilerini yakalamak, seviyeyi yükseltmek, edinilen teknolojik bilgiyle yeniden üretebilme ve tasarımlama yeteneğini kazanmak, tarım makinaları konusunda uzmanlașmak için faaliyetlerini sürdürmektedir. 


\section{KAYNAKLAR}

Ağır H. ve Utlu S., 2011 . "AR-GE Harcamaları ile Ekonomik Büyüme Arasındaki Nedensellik illișkileri: OECD Ülkeleri Örneği". Uluslararası 9. Bilgi Ekonomi ve Yönetim Kongresi Bildirileri, 2011, 269-280.

Birișik, N., 2019. Küresel ve Ulusal Ölçekte Tarım ve Gıda Politikaları "Gerçekler, Sorunlar ve Çözüm Önerileri" MemurSen Konfederasyonu Tarım-Orman Çalıșanları Birliği Sendikası Yayınları, ISBN 978-605-85250-2-3. 303 s.

FAO www.fao.org

https://www.iotforall.com/smart-farming-future-ofagriculture
Anonim 2020 https://www.oaibftp.com/arge3/tar-maketk-rap.pdf

https://www.tarimorman.gov.tr/TAGEM/Belgeler/yayin/ 5\%C3\%BCt\%20Sekt\%C3\%B6r\%20Politika\%20Belgesi\%20 2018-2022.pdf Aksoy, A. R., Hayvan Islahı Ders Notları, Kafkas Üniversitesi Veteriner Fakültesi, Kars 2003.

https://www.tr.undp.org/content/turkey/tr/home/ sustainable-development-goals/goal-2-zero-hunger.html

https://www.taider.org.tr/images/belgeler/kuresel_ rekabet_gucunun_anahtari_arge_ve_inovasyon.pdf. 